\title{
Gender Equalities in Entrepreneurship: How Close, Or Far, Have We Come in Italy?
}

\author{
Diego Matricano ${ }^{1} \&$ Mario Sorrentino ${ }^{1}$ \\ ${ }^{1}$ Department of Management, Università degli Studi della Campania "Luigi Vanvitelli”, Capua (CE), Italy. \\ Correspondence: Diego Matricano, Department of Management, Università degli Studi della Campania "Luigi \\ Vanvitelli”, Corso Gran Priorato di Malta-81043 Capua (CE), Italy. E-mail: diego.matricano@unicampania.it
}

Received: January 3, 2018

doi:10.5539/ijbm.v13n3p75

\begin{abstract}
Female entrepreneurship is a relevant phenomenon all around the world. In reference to Italy, there has been a growing involvement of women in the creation of start-ups only over the last decades. However, from an extensive literature review, it results that there are no relevant studies aiming to test the main differences between male and female Italian entrepreneurs, especially in reference to the levers affecting their propensity to launch new start-ups. The present paper tries to reduce this gap by testing whether male and female Italian entrepreneurs differ in terms of intellectual capital affecting their propensity to launch new start-ups. The sample used for the present research derives from Global Entrepreneurship Monitor - GEM website, refers to 2013 and comprehends 1,055 female and 997 male entrepreneurs. Results show that male and female Italian entrepreneurs are more similar than expected. Some reflections about the state-of-the-art of female entrepreneurship in Italy and some hints for future research are included in the last section of the paper.
\end{abstract}

Keywords: female entrepreneurship, entrepreneurial propensity, intellectual capital, start-ups

\section{Introduction}

The affirmation of female entrepreneurship as an autonomous field of research has not been so easy (Allen et al., 2007). Over the Eighties, in fact, entrepreneurship scholars have looked at this field of research according to different approaches. Gutek and Larwood (1989) are the promoters of one of the more extreme approaches. According to the scholars, "men had carriers, women had temporary employment or jobs that took second place to family interests and obligations" (ibidem, pg. 8). Put simply, according to the two scholars the involvement of women in entrepreneurship is not worth being investigated since it is a secondary choice, following their interest toward family. Without getting into this matter, it is enough saying that other scholars have not embraced this approach. In contrast to this approach, in fact, entrepreneurship scholars have adopted two others. The former is based on the idea that there are no meaningful differences between male and female entrepreneurs (Chaganti, 1986; Birley, 1989); the latter assumes that some differences between them do exist (Gallos, 1989; Gutek \& Larwood, 1989; Brush, 1992; Powell \& Mainiero, 1992).

According to the former approach, it is not worth explaining the different involvement of men and women in entrepreneurship according to their gender. Both of them, in fact, are involved in a process that is based on the identification of entrepreneurial opportunities - which can be recognized, discovered or created (Sarasvathy et al., 2005; Alvarez \& Barney 2007, 2008), that passes through the selection of some of them (Venkataraman, 1997; Shane \& Venkataraman, 2000; Shane, 2003; Aldrich \& Ruef, 2006) and ends with exploitation of the best one (Shane \& Venkataraman, 2000; Shane, 2003; Foss \& Foss, 2004; Plummer et al., 2007). All the activities carried out over this process do not depend on gender (Chaganti, 1986; Birley, 1989; Kepler \& Shane, 2007).

According to the latter approach, instead, social differences between men and women are so relevant that they cannot be ignored. This stands for entrepreneurship as well. This second approach has received more attention. Some entrepreneurship scholars (Lerner et al., 1997; Langowitz \& Minniti, 2007; Minniti \& Nardone, 2007; Minniti, 2010), in fact, underline the role that women have in the society, its evolution over the decades and its impact on everyday life. For this reason, it is appropriate to investigate female entrepreneurship according to a different approach.

The present study is in line with the latter approach. Thus the assumption that some differences between male 
and female entrepreneurs can exist is embraced herein. In particular, the aim of this paper is to test empirically if there is any difference between male and female Italian entrepreneurs in reference to their propensity to launch new start-ups. In order to achieve the above-cited aim, the paper is structured as it follows. In section two, an extensive literature review is presented. It is focused on the differences between male and female and on their propensity to launch new start-ups. A special focus on Italian female entrepreneurs is included in the second part of this section. After this, in section three, two theoretical frameworks generally used to investigate the individual propensity to launch new start-ups are compared. The first refers to the concept of Entrepreneurial Orientation (EO) while the second refers to the concept of Intellectual Capital (IC). After choosing the most suitable theoretical framework - in this case the one related to IC, the research design is presented in section four. Particular interest is paid on the data deriving from Global Entrepreneurship Monitor - GEM website, referring to 2013 and comprehending 1,055 female and 997 male entrepreneurs and on the methodology (binary logistic regression model). In the same section, the empirical results are presented and discussed. Eventually, in section five, after highlighting the main limitations of the paper, some conclusions are drawn. In the last part of the section, some hints for future research are suggested.

\section{Literature Review}

Over the years, scholars have largely investigated the topic of female entrepreneurship (Hisrich \& Brush, 1984, 1986; Bowen \& Hisrich, 1986; Chaganti, 1986; Scott, 1986; Aldrich et al., 1989; Birley, 1989; Nelson, 1989; Stoner et al., 1990; Brush, 1992; Cromie \& Birley, 1992; Smith et al., 1992; Aldrich, 1999; Brush et al., 2001; Sarri \& Trihopoulou, 2005; Ahl, 2006; Allen et al., 2007; Zhang et al., 2009; Minniti, 2010; Jennings \& Brush, 2013). Since it is not possible to recall all the results achieved by the above contribution, only the ones that are more related with the propensity to launch new start-ups are going to be considered.

Brush et al. (2001) authored an interesting study that is worth recalling herein. It is entitled "The Diana Project. Women Business Owners and Equity Capital: The Myths Dispelled" and it aims to dismantle eight myths about female entrepreneurship: 1) women don't want to own high growth businesses; 2) women don't have the right educational backgrounds to build large ventures; 3 ) women don't have the right types of experience to build large ventures; 4) women aren't in the network and lack the social contacts to build a credible venture; 5) women don't have the financial savvy or resources to start high growth businesses; 6) women don't submit business plans to equity providers; 7) women-owned ventures are in industries unattractive to venture capitalists; and 8) women are not a force in the venture capital industry. The discussion about the eight myths helps to redefine the way of looking at female entrepreneurship and their involvement in the creation of start-ups.

Minniti (2010) authored one of the most interesting and complete studies about female entrepreneurship (the sample comprehended individuals from thirty-four nations). The scholar has investigated objective and subjective microeconomic factors. The former group comprehends age, education, working status, earnings and networking activities. The latter group includes the discovery of entrepreneurial opportunities, self-confidence, risk management and locus of control. According to the scholar, the only objective factor that affects the entrepreneurial activity of female entrepreneurs is networking. This result is in line with previous studies (Aldrich, 1999; Allen et al., 2007) even if the debate about this topic is still open. In particular, the relatives network has been investigated since it can have both a positive and negative impact on female entrepreneurship (Hisrich \& Brush, 1986; Stoner et al., 1990) or, on the opposite, it can offer a very relevant support both in economic and emotional terms (Nelson, 1989). Among the subjective factors, instead, only self-confidence is relevant for female entrepreneurs.

Zhang et al. (2009) have investigated four main differences that might arise between male and female entrepreneurs over the pre-start-up phase. Achieved results show that female entrepreneurs need to face more obstacles in order to launch their new ventures. They are less inclined toward seeking for angel financing, they invest less resources (both financial and human ones), they cannot easily reach potential customers outside their network and they need to provide more guarantees for a loan.

Eventually, Chaganti (1986) and Brush (1992) have focused their attention on some managerial aspects related to the start-up phase and they have disclosed very interesting results. First of all, female entrepreneurs manage their firms in an adaptive and flexible way. Put simply, they tend to avoid long-term decisions. Second, they use a style of leadership aiming to involve and motivate human resources working with them. In other words, they are more sympathetic than men. Third, female entrepreneurs do not evaluate results only in terms of revenues. They consider personal goals as important as economic results.

The above results underline that some differences between male and female entrepreneurs do exist. However, since entrepreneurship is a phenomenon that strictly depends on the context in which it takes place (Zanni, 1995; 
Low, MacMillan, 1988; Reynolds et al., 2001, 2002; Thornton, Flynn, 2003; Autio, 2005; Whetten, 2009; Sorrentino, 2012), it is important to try to rebuild female entrepreneurship in Italy.

One of the most authoritative sources about female entrepreneurship is a report published in 2016 by Unioncamere (the Italian Association of the Chambers of Commerce) in collaboration with Ministry of Economic Development, Presidency of the Council of Ministers - Department for Equal Opportunities and entitled "Impresa in Genere. $3^{\circ}$ Rapporto nazionale sull'imprenditoria femminile". The data included in the above report (published in 2016 and referred to 2014) help to shape the profile of women entrepreneurs in Italy.

According to the above report (ibidem, pp. 14-17), female entrepreneurs in Italy mainly work in service industries and launch micro ventures. As for the industry, the report "Impresa in Genere" (2016) highlights that $65,5 \%$ of female entrepreneurs are involved in tertiary sector (men involved in the same sector are only 54\%). In reference to the dimension of the venture, $97 \%$ of female entrepreneurs manage less than nine employees. Out of this, $68 \%$ of female entrepreneurs manage venture occupying no more one employee. This confirms the idea of micro ventures. Both the above choices (related to the industry and to dimension) seem to be due to the opportunity to combine personal and working duties (Cliff, 1998) since women assume that manufacturing sectors and medium or big companies are more complex and more difficult to be managed. On the contrary, male entrepreneurs in Italy are less interested in service industries and are more inclined to launch bigger ventures.

Female entrepreneurs in Italy are self-employed because of granted flexibility (De Martino \& Barbato, 2003), and their working expectations (Verheul et al., 2005). In reference to the working expectations, it seems to be confirmed the idea that female entrepreneurs manage ventures growing and developing over longer times (Verheul et al., 2005). This explains their greater working expectations than men.

Moreover, female entrepreneurs in Italy are opportunity entrepreneurs and not necessity entrepreneurs (Reynolds et al. 2001, 2002; De Martino \& Barbato, 2003; Harding et al. 2006; Minniti et al. 2006; Sternberg et al. 2006; Block and Wagner 2007). They are satisfied with the choice to be entrepreneurs also because they decide to launch new start-ups because of the high education they have (Idris, 2008). In this way, as argued in the report, female entrepreneurs reduce the gap with male entrepreneurs.

At this stage, a preliminary reflection about gender equality is necessary. Even if it seems that something is changing in reference to gender equality - meaning that in reference to economic and working decisions both men and women can access to resources and opportunities and in reference to everyday life both men and women can behave and express their expectations and needs in a different way (Kabeer, 2005, 2016; Lewis \& Giullari, 2005; Grip et al., 2016) - some differences between male and female entrepreneurs still exist in Italy.

Since some differences still exist, it is interesting to test if male and female entrepreneurs in Italy differ in terms of levers affecting their inclination to launch new start-ups.

\section{Theoretical Framework and Research Hypotheses}

As already anticipated, the aim of this paper is to test empirically if there is any difference between male and female Italian entrepreneurs in reference to the levers affecting their propensity to launch new start-ups. For this reason, it is appropriate to choose the most suitable theoretical frameworks.

Generally speaking, when dealing with propensity to launch new start-ups, management scholars can refer to the Theory of Planned Behaviour (Ajzen, 1991), the Perceived Behavioural Control (Krueger et al., 2010), the attitude toward entrepreneurship (Engle et al., 2010), the social norms or the social evaluation of entrepreneurship (White et al., 2009). However, great attention is paid on two main theoretical frameworks that are used to explain inclination towards entrepreneurship very often: the former is related to Entrepreneurial Orientation (EO), the latter is related to Intellectual Capital (IC).

Even if the origins of EO can be dated back to 1973 when Mintzberg started theorizing about strategic decision-making, it is only with Miller's contribution (1983) that EO is formalized and the three dimensions composing it (innovativeness, risk taking, and proactiveness) are clearly defined. Since then, several management scholars have investigated the concept (Covin \& Slevin, 1989, 1991; Lumpik \& Dess, 1996; Lyon et al., 2000; Covin et al., 2006; Hughes \& Morgan, 2007; Lumpik et al., 2009; Covin \& Wales, 2012; Wales et al., 2013; Wales, 2016). In particular, management scholars have focused their attention on the items used for the measurement of EO. For this reason, they have questioned, criticised, enlarged or modified the three dimensions (innovativeness, risk taking, and proactiveness) composing EO (Lumpik \& Dess, 1996; Hughes \& Morgan, 2007). Since it is a tall order to define the number of dimension composing EO, it is accepted herein the original proposal (Miller, 1983). Thus, Lumpkin and Dess (2001, pg. 431) argue: "innovativeness refers to a willingness to support creativity and experimentation in introducing new products/services, and novelty, technological 
leadership and $R \& D$ in developing new processes. Risk taking means a tendency to take bold actions such as venturing into unknown new markets, committing a large portion of resources to ventures with uncertain outcomes, and/or borrowing heavily. Proactiveness is an opportunity-seeking, forward-looking perspective involving introducing new products or services ahead of the competition and acting in anticipation of future demand to create change and shape the environment". The dimensions reported above have been largely used also to test gender differences among entrepreneurs (Hansen et al., 2011; Lim \& Envick, 2011; Goktan \& Gupta, 2015) and so the framework could be useful for the present study as well.

Another framework that is more and more used by management scholars in order to investigate the individual propensity to launch new start-ups is the one based on IC (Peña, 2002; Hayton, 2005; Hormiga et al., 2011; Link and Ruhm, 2011; Musteen and Ahsan, 2013; Matricano, 2016). Galbraith (1969) proposed this framework in order to investigate the intellectual contribution made by individuals working in knowledge-intensive ventures. Generally speaking, entrepreneurship scholars investigating IC consider three dimensions: human, structural and relational capital (Sullivan, 1999; Brennan and Connell, 2000; Petty and Guthrie, 2000; Sanchez et al., 2000; Roos et al., 2001; Peña, 2002; Kaufmann and Schneider, 2004; Boedker et al., 2005; Hormiga et al., 2011; Musteen and Ahsan, 2013). Despite other proposals - considering external (customer-related), internal (structural) and human capital (Sveiby, 1997; Roos et al., 1997; Stewart, 1997; Bontis et al., 2000) or market, human, intellectual and infrastructural capital (Brooking, 1996), or even human, customer, structural, social, technological and spiritual capital (Khalique et al., 2011, 2015) - there is a general agreement on the idea that IC is made up of relational, structural and human capital. Relational capital stands for the tangible and intangible value of all the established relationships (Bontis, 2001; Montequin et al., 2006; Cabrita and Bontis, 2008; Wu et al., 2008; Hsu and Fang, 2009). Structural capital, instead, refers to transformation of human and relational capital into new knowledge (Hormiga et al., 2011). Eventually, by human capital, entrepreneurship scholars refer to individual competences (such as knowledge, skills, and personal capabilities), motivation and leadership and intellectual agility (Khalique et al., 2015). Also the above dimensions have been used in order to study female entrepreneurship (Minniti, 2010).

Both the frameworks can be useful to test if there is any difference between male and female Italian entrepreneurs in reference to their propensity to launch new start-ups. The choice, of course, need to be rooted in the topic of research, i.e. female entrepreneurship. A very important contribution in this vein comes from Jalbert (2000) who argues that in reference to female entrepreneurship it is always very important to consider the industry female entrepreneurs are in. High- or low-tech industries affect the dynamics of female entrepreneurs. Since in the present paper there is no specific reference to high-tech start-ups, and in particular there is no reference to innovativeness (technological leadership and R\&D activities), the IC framework (comprehending relational, structural, and human capital) seems more befitting to the present study (Table 1). See also Matricano (2016).

Table 1. The theoretical framework

\begin{tabular}{lll}
\hline Independent variables & & Dependent variables \\
\hline Relational capital & $\rightarrow$ & \\
Structural capital & $\rightarrow$ & Propensity to launch new start-ups \\
Human capital & $\rightarrow$ & \\
\hline
\end{tabular}

In order to test if there is any difference between male and female Italian entrepreneurs in reference to their propensity to launch new start-ups, three research hypotheses - respectively referred to human, structural and relational capital - are proposed. In reference to relational capital (H1), it is possible to hypothesize that:

H1a: The relationship between relational capital and individual propensity to launch new start-ups is stronger for Italian male entrepreneurs.

The rival hypotheses assumes that:

H2b: The relationship between relational capital and individual propensity to launch new start-ups is stronger for Italian female entrepreneurs.

In reference to structural capital (H2), it is possible to hypothesize that:

H2a: The relationship between structural capital and individual propensity to launch new start-ups is stronger for 
Italian male entrepreneurs.

The rival hypotheses assumes that:

H2b: The relationship between structural capital and individual propensity to launch new start-ups is stronger for Italian female entrepreneurs.

In reference to human capital (H3), it is possible to hypothesize that:

H3a: The relationship between human capital and individual propensity to launch new start-ups is stronger for Italian male entrepreneurs.

The rival hypotheses assumes that:

H3b: The relationship between human capital and individual propensity to launch new start-ups is stronger for Italian female entrepreneurs.

\section{Research Design and Results}

In order to pursue the aim of this paper, i.e. to test if there is any difference between male and female Italian entrepreneurs in reference to their propensity to launch new start-ups, binomial logistic regression models are estimated for male and female entrepreneurs. Binomial logistic regression model is chosen according to the nature of data that - as already said - are second hand data. GEM considers relational, structural, and human capital (the independent variables in the model) and propensity to launch new start-ups (the dependent variables in the model) as binary variables. All of the variables are coded 0 if individuals do not have human, structural, and relational capital or if they do not have any propensity to launch new start-ups or they are coded 1 if they have. This is the model 1 that is going to be tested.

Statistical elaborations present two main problems: robustness of results and collinearity. In order to guarantee robustness of results it is appropriate to refer to a big sample of respondents. In this case, the choice to download data from GEM website guarantee a certain amount of answers. 2,052 are the Italian entrepreneurs responding to the survey. The parameter "gender" has been considered when carrying out the sampling procedure. This parameter has defined two mutually exclusive and collectively exhaustive groups -997 are male while 1,055 are female entrepreneurs (see Table 2). The sampling procedure seems promising also in reference to the analysis of achieved results. By comparing male and female entrepreneurs, new insights can derive.

Table 2. Samples of respondents by gender

\begin{tabular}{cc}
\hline Gender & Sample size \\
\hline Male & 997 \\
Female & 1,055 \\
TOTAL & 2,022 \\
\hline
\end{tabular}

Always in reference to robustness of results, it is appropriate to include some control variables in the model. These variables, which are related to the dependent variable but from another point of view, can strengthen the robustness of results. In this paper, two control variables are considered: fear of failure and level of competition. Of course, in order to include them in binomial logistic regression model, they both are binomial variables coded 0 if entrepreneurs do not have fear of failure and do not perceive high competition and coded 1 if entrepreneur have fear of failure and perceive a high level of competition. This is the model 2 that is going to be tested.

In order to avoid collinearity among independent variables (the second problem linked to statistical elaborations), the variance inflation factor (VIF) is considered. In particular, attention needs to be paid over the calculated collinearity statistics, in particular tolerance and VIF, and over collinearity diagnostics, in particular condition index. In Table 3, collinearity statistics (in particular tolerance and VIF) are shown. 
Table 3. Collinearity statistics of models 1 and 2 by gender

\begin{tabular}{lcccccccc}
\hline & \multicolumn{4}{c}{ Male } & \multicolumn{4}{c}{ Female } \\
\hline & \multicolumn{2}{c}{ Model 1 } & \multicolumn{2}{c}{ Model 2 } & \multicolumn{2}{c}{ Model 1 } & \multicolumn{2}{c}{ Model 2 } \\
& Tolerance & VIF & Tolerance & VIF & Tolerance & VIF & Tolerance & VIF \\
\hline Relational capital & 0.937 & 1.068 & 0.925 & 1.081 & 0.987 & 1.013 & 0.978 & 1.022 \\
Structural capital & 0.973 & 1.027 & 0.967 & 1.034 & 0.980 & 1.020 & 0.977 & 1.023 \\
Human capital & 0.946 & 1.057 & 0.933 & 1.072 & 0.982 & 1.018 & 0.976 & 1.025 \\
Fear of failure & & & 0.991 & 1.009 & & & 0.995 & 1.005 \\
Level of competition & & & 0.964 & 1.038 & & & 0.986 & 1.014 \\
\hline
\end{tabular}

According to the principles of statistics, values of tolerance need to be higher than 0,50 and values of VIF need to be lower than 2. All the values included in Table 3 respect the above limits.

In order to be sure that there is no collinearity among independent variables, it is appropriate to calculate the condition index, a value included among collinearity diagnostics (Table 4).

Table 4. Collinearity diagnostics of models 1 and 2 by gender

\begin{tabular}{lcccc}
\hline & \multicolumn{2}{c}{ Male } & \multicolumn{2}{c}{ Female } \\
\hline & $\begin{array}{c}\text { Model 1 } \\
\text { Condition index }\end{array}$ & $\begin{array}{c}\text { Model 2 } \\
\text { Condition index }\end{array}$ & $\begin{array}{c}\text { Model 1 } \\
\text { Condition index }\end{array}$ & $\begin{array}{c}\text { Model 2 } \\
\text { Condition index }\end{array}$ \\
\hline Constant & 1.000 & 1.000 & 1.000 & 1.000 \\
Relational capital & 1.834 & 1.743 & 1.536 & 1.592 \\
Structural capital & 1.977 & 1.934 & 1.582 & 1.718 \\
Human capital & 2.475 & 2.061 & 1.956 & 1.787 \\
Fear of failure & & 2.342 & & 1.952 \\
Level of competition & & 3.591 & & 3.460 \\
\hline
\end{tabular}

According to the principles of statistics, values of condition index higher than thirty disclose strong collinearity; values comprehended between fifteen and thirty reveal a suspected collinearity; values lower than fifteen do not show any collinearity among independent variables. As shown by values included in Table 4, there is no collinearity among independent variables.

At this stage, it is possible to elaborate binomial logistic regression models. Elaborations have been conducted using a forward Wald approach (see Table 5).

Table 5. Estimated binomial logistic regression models by gender

\begin{tabular}{lcccc}
\hline & \multicolumn{2}{c}{ Male } & \multicolumn{2}{c}{ Female } \\
\cline { 2 - 5 } & Model 1 & Model 2 & Model 1 & Model 2 \\
\hline Constant & $\mathbf{0 . 0 5 1}$ & $\mathbf{0 . 0 5 4}$ & $\mathbf{0 . 0 6 3}$ & $\mathbf{0 . 0 6 2}$ \\
& $\mathbf{( 0 . 0 0 0 )}$ & $\mathbf{( 0 . 0 0 0 )}$ & $\mathbf{( 0 . 0 0 0 )}$ & $\mathbf{( 0 . 0 0 0 )}$ \\
& & & & \\
Independent variables & & & & \\
Relational capital & $\mathbf{1 . 5 7 4}$ & 3.401 & 0.061 & 0.001 \\
& $\mathbf{( 0 . 0 3 6 )}$ & $(0.065)$ & $(0.804)$ & $(0.970)$ \\
Structural capital & 2.263 & 2.372 & 2.182 & 2.533 \\
& $(0.133)$ & $(0.124)$ & $(0.140)$ & $(0.112)$ \\
Human capital & $\mathbf{6 . 0 9 0}$ & $\mathbf{6 . 3 0 2}$ & $\mathbf{3 . 6 7 3}$ & $\mathbf{3 . 5 5 1}$ \\
& $\mathbf{( 0 . 0 0 0 )}$ & $\mathbf{( 0 . 0 0 0 )}$ & $\mathbf{( 0 . 0 0 0 )}$ & $\mathbf{( 0 . 0 0 0 )}$ \\
Control variables & & & & \\
Fear of & & 0.325 & & 1.165 \\
failure & & $(0.569)$ & & $(0.280)$ \\
Level of competition & & $\mathbf{2 . 3 4 8}$ & & $\mathbf{3 . 4 1 1}$ \\
Model diagnostics & & $\mathbf{( 0 . 0 3 8 )}$ & & $\mathbf{( 0 . 0 3 0 )}$ \\
\hline
\end{tabular}




\begin{tabular}{|c|c|c|c|c|}
\hline Number of cases & 997 & 997 & 1,055 & 1,055 \\
\hline Percentage of correct predictions & $87.1 \%$ & $87.1 \%$ & $91.2 \%$ & $91.2 \%$ \\
\hline$\chi^{2}$ of Omnibus test & $\begin{array}{l}94.737 \\
(0.000)\end{array}$ & $\begin{array}{l}94.468 \\
(0.000)\end{array}$ & $\begin{array}{l}32.121 \\
(0.000)\end{array}$ & $\begin{array}{l}36.109 \\
(0.000)\end{array}$ \\
\hline Degree of freedom of Omnibus test & 2 & 2 & 1 & 2 \\
\hline Nagelkerke $\mathrm{R}^{2}$ (pseudo $\mathrm{R}^{2}$ ) & 0.169 & 0.168 & 0.067 & 0.075 \\
\hline
\end{tabular}

The above results need to be carefully analyzed. From model 1 about male entrepreneurs, it results that relational and human capitals affect propensity to launch new start-ups (the coefficients are respectively 1.574 and 6.090). Attention needs to be paid over $\mathrm{H} 1$ and $\mathrm{H} 3$. By considering also the control variables, the achieved results change. From model 2, in fact, it results that only human capital affects the propensity to launch new start-ups of male entrepreneurs in Italy (the coefficient is 6.302). Thus $\mathrm{H} 3$ is the only hypothesis that needs to be considered. Level of competition is the control variable that gives robustness to the theoretical model.

In reference to female entrepreneurs, model 1 shows that only human capital affects the propensity to launch new start-ups (the coefficient is 3.673). Attention needs to be paid only over H3. Even after the introduction of the control variables, the result is still the same. From model 2, in fact, it results that it is only human capital that still affects the propensity to launch new start-ups of female entrepreneurs in Italy (the coefficient is 3.551). Again, level of competition is the control variable that gives robustness to the theoretical model and only $\mathrm{H} 3$ is the hypothesis that needs to be considered. This means that for Italian male and female entrepreneurs, knowledge, skills, and personal capabilities (considered herein as human capital) are the only factors that affect the propensity to launch new ventures. In reference to the IC framework, this result is very interesting since it drives to question about the relevance of structural and relational capital that - instead - have been relevant in previous entrepreneurship studies (Matricano, 2016, 2017).

From the above results, it seems that in reference to the propensity to launch new ventures, male and female entrepreneurs in Italy have achieved a kind of gender equality. For both of them, in fact, only human capital seems relevant when investigating the levers affecting the inclination to launch new ventures. However, some differences still exist. In reference to $\mathrm{H} 3$, it results that $\mathrm{H} 3 \mathrm{a}$ is confirmed while $\mathrm{H} 3 \mathrm{~b}$ is not. This means that the relationship between human capital and propensity to launch new start-ups is stronger for Italian male entrepreneurs (6.302) rather than for Italian female entrepreneurs (3.551).

\section{Conclusion and Further Developments}

The present paper has investigated the phenomenon of female entrepreneurship in Italy. Achieved results are very interesting from an empirical and a theoretical point of view.

From an empirical point of view, the present study discloses intriguing implications. Achieved results, in fact, show that only human capital is relevant for both male and female entrepreneurs in Italy. Both relational capital and structural capital are not significant, neither for male nor for female entrepreneurs. This implies that equalities exist between male and female entrepreneurs. However, a significant difference emerges in reference to the coefficients: the relationship between human capital and propensity to launch new start-ups is stronger for Italian male entrepreneurs rather than for Italian female entrepreneurs. Respectively, the coefficients are 6.302 for men and 3.551 for women.

Achieved results have important implications for entrepreneruship researchers. Despite the difference between the coefficients, in fact, it is very relevant the fact that only human capital is relevant for both male and female entrepreneurs in Italy. Put simply, this paper has started from the idea that some differences exist between male and female entrepreneurs in terms of levers affecting their inclination to launch new start-ups but then it has achieved the opposite result. Empirical evidences drive to change the approach to female entrepreneurship. Entrepreneurship - both male and female one - does not depend on gender (Chaganti, 1986; Birley, 1989; Kepler \& Shane, 2007).

Hopefully, the above considerations can be relevant for the development of further theories about female entrepreneurship. In particular, it would be very attractive to investigate the antecedents that might have driven towards gender equality in entrepreneurship - in Italy or in other countries - or the consequences related to it. In reference to the antecedents, it would be interesting to pay attention and speculate on the social and cultural changes that are taking place in favour of women and that make scholars admit that entrepreneurship is not a male activity any more (Narayanasamy et al., 2011). In reference to the consequences, instead, it would be interesting to study and test if gender equality exists also in terms of achieved success (McClelland et al., 2005). 
The present paper discloses that many steps have been taken for the recognition of gender equality in entrepreneurship but - at the same time - it reminds that many steps still have to be taken for its effective achievement.

\section{Acknowledgments}

Although this article is the result of a joint effort of analysis and reflection, DM authored sections 1, 3, 4 and 5 and MS authored section 2. Both the authors read and approved the final manuscript.

\section{References}

Ahl, H. (2006). Why research on women entrepreneurs needs new directions. Entrepreneurship: Theory and Practice, 30(5), 595-621. https://doi.org/10.1111/j.1540-6520.2006.00138.x

Ajzen, I. (1991). The theory of planned behavior. Organizational Behavior and Human Decision Processes, 50(2), 179-211. https://doi.org/10.1016/0749-5978(91)90020-T

Aldrich, H. E. (1999). Organization Evolving. London, UK: Sage Publications.

Aldrich, H. E., \& Ruef, M. (2006). Organizations Evolving. Second edition, Thousand Oaks, CA: Sage Publications.

Aldrich, H., Reese, P. R., \& Dubini, P. (1989). Women on the verge of a breakthrough: networking among entrepreneurs in the United States and Italy. Entrepreneurship \& Regional Development, 1(4), 339-356. https://doi.org/10.1080/08985628900000029

Allen, E., Langowitz, N., \& Minniti, M. (2007). The 2006 Global Entrepreneurship Monitor Special Topic Research: Women in Entrepreneurship, Center for Women Leadership, Babson Park, MA: Babson College.

Alvarez, S. A., \& Barney, J. B. (2007). Guest editors' introduction. The entrepreneurial theory of the firm. Journal of Management Studies, 44(7), 1057-1063. https://doi.org/10.1111/j.1467-6486.2007.00721.x

Alvarez, S. A. \& Barney, J. B. (2008). Opportunities, organizations, and entrepreneurship. Strategic Entrepreneurship Journal, 2(3), 171-173. https://doi.org/10.1002/sej.52

Autio, E. (2005). Global Entrepreneurship Monitor - Executive Report, Babson Park, MA: Babson College.

Birley, S. (1989). Female entrepreneurs: Are they really any different? Journal of Small Business Management, 27(5), 32-37.

Block, J. H., \& Wagner, M. (2007). Opportunity recognition and exploitation by necessity and opportunity entrepreneurs: empirical evidence from earnings equations. In Proceedings of the Sixty-Sixth Annual Meeting of Academy of Management. Philadelphia (PA): Academy of Management.

Boedker, C., Guthrie, J., \& Cuganesan, S. (2005). An integrated framework for visualizing intellectual capital. Journal of Intellectual Capital, 6(4), 510-527. https://doi.org/10.1108/14691930510628799

Bontis, N. (2001). Assessing knowledge assets: A review of the models used to measure intellectual capital. International Journal of Management Reviews, 3(1), 41-60. https://doi.org/10.1111/1468-2370.00053

Bontis, N., Keow, W. C., \& Richardson, S. (2000). Intellectual capital and business performance in Malaysian industries. Journal of Intellectual Capital, 1(1), 85-100. https://doi.org/10.1108/14691930010324188

Bowen, D. D., \& Hisrich, R. D. (1986). The female entrepreneur: a career development perspective. Academy of Management Review, 11(2), 393-407. https://doi.org/10.5465/AMR.1986.4283366

Brennan, N., \& Connell, B. (2000). Intellectual capital: current issues and policy implication. Journal of Intellectual Capital, 1(3), 206-240. https://doi.org/10.1108/14691930010350792

Brooking, A. (1996). Intellectual Capital. London, UK: International Thomson Business Press.

Brush, C. (1992). Research on women business owners: past trends, a new perspective and future directions. Entrepreneurship: Theory and Practice, 16(4), 5-30. https://doi.org/10.1177/104225879201600401

Brush, C., Carter, N., Gatewood, E., Greene, P., \& Hart, M. (2001). The Diana Project. Women Business Owners and Equity Capital: The Myths Dispelled, Report by Kauffman Center for Entrepreneurial Leadership, retrieved from http://www.entreworld.org

Cabrita, M. D., \& Bontis, N. (2008). Intellectual capital and business performance in the Portuguese banking industry. International Journal of Technology Management, 43(1-3), 212-237. https://doi.org/10.1504/IJTM.2008.019416 
Chaganti, R. (1986). Management in women-owned enterprises. Journal of Small Business Management, 24, $18-29$.

Cliff, J. E. (1998). Does one size fit all? Exploring the relationship between attitudes towards growth, gender, and business size. Journal of Business Venturing, 13(6), 523-542. https://doi.org/10.1016/S0883-9026(97)00071-2

Covin, J. G., \& Slevin, D. P. (1989). Strategic management of small firms in hostile and benign environments. Strategic Management Journal, 10(1), 75-87. https://doi.org/10.1002/smj.4250100107

Covin, J. G., \& Slevin, D. P. (1991). A conceptual model of entrepreneurship as firm behavior. Entrepreneurship: Critical Perspectives on Business and Management, 3, 5-28.

Covin, J. G., \& Wales, W. J. (2012). The measurement of entrepreneurial orientation. Entrepreneurship: Theory and Practice, 36(4), 677-702. https://doi.org/10.1111/j.1540-6520.2010.00432.x

Covin, J. G., Green, K. M., \& Slevin, D. P. (2006). Strategic process effects on the entrepreneurial orientation-sales growth rate relationship. Entrepreneurship: Theory and Practice, 30(1), 57-81. https://doi.org/10.1111/j.1540-6520.2006.00110.x

Cromie, S., \& Birley, S. (1992). Networking by female business owners in Northern Ireland. Journal of Business Venturing, 7(3), 237-251. https://doi.org/10.1016/0883-9026(92)90029-Q

De Martino, R., \& Barbato, R. (2003). Differences between women and men MBA entrepreneurs: Exploring family flexibility and wealth creation as career motivators. Journal of Business Venturing, 18(6), 815-832. DOi: https://doi.org/10.1016/S0883-9026(03)00003-X

Engle, R. L., Dimitriadi, N., Gavidia, J. V., Schlaegel, C., Delanoe, S., Alvarado, I., \& Wolff, B. (2010). Entrepreneurial intent: a twelve-country evaluation of Ajzen's model of planned behavior. International Journal of Entrepreneurial Behavior \& Research, 16(1), 35-57. https://doi.org/10.1108/13552551011020063

Foss, K., \& Foss, N. J. (2004). The next step in the evolution of the RBV: Integration with transaction cost economics. Management Review, 15(1), 107-121.

Galbraith, J. K. (1969). The consequences of technology. Journal of Accountancy, 127(6), 44-56

Gallos, J. V. (1989). Exploring women's development: implications for career theory, practice, and research. In M. B. Arthur, D. T. Hall, \& B. S. Lawernce (Eds.), Handbook of Career Theory. New York, NY: Cambridge University.

Goktan, A. B., \& Gupta, V. K. (2015). Sex, gender, and individual entrepreneurial orientation: evidence from four countries. International Entrepreneurship and Management Journal, 11(1), 95-112. https://doi.org/10.1007/s11365-013-0278-z

Grip, L., Engström, L. G., Krekula, C., \& Karlsson, S. (2016). The woman as problem and solution-analysis of a gender equality initiative within the Swedish Rescue Services. NORA-Nordic Journal of Feminist and Gender Research, 24(2), 95-109.

Gutek, B. A. \& Larwood, L. (1989). Women's Career Development, Newbury Park, CA: Sage.

Hansen, J. D., Deitz, G. D., Tokman, M., Marino, L. D., \& Weaver, K. M. (2011). Cross-national invariance of the entrepreneurial orientation scale. Journal of Business Venturing, 26(1), 61-78. https://doi.org/10.1016/j.jbusvent.2009.05.003

Harding, R., Brooksbank, D., Hart., M, Jones-Evans, D., Levie, J., O’Reilly, J., \& Walker, J. (2006). Global Entrepreneurship Monitor: Country Report United Kingdom 2005. London, UK: London Business School.

Hayton, J. C. (2005). Competing in the new economy: the effect of intellectual capital on corporate entrepreneurship in high-technology new ventures. $R \& D$ Management, 35(2), 137-155. https://doi.org/10.1111/j.1467-9310.2005.00379.x

Hisrich, R. D., \& Brush, C. G. (1984). The woman entrepreneur: management skills and business problems. Journal of Small Business Management, 22(1), 30-38.

Hisrich, R. D. \& Brush, C. G. (1986) The Woman Entrepreneur. Lexington, MS: Lexington Books.

Hormiga, E., Batista-Canino, R. M., \& Sánchez-Medina, A. (2011). The role of intellectual capital in the success of new ventures. International Entrepreneurship and Management Journal, 7(1), 71-92. https://doi.org/10.1007/s11365-010-0139-y 
Hsu, Y. H., \& Fang, W. (2009). Intellectual capital and new product development performance: the mediating role of organizational learning capability. Technological Forecasting and Social Change, 76(5), 664-677. https://doi.org/10.1016/j.techfore.2008.03.012

Hughes, M., \& Morgan, R. E. (2007). Deconstructing the relationship between entrepreneurial orientation and business performance at the embryonic stage of firm growth. Industrial Marketing Management, 36(5), 651-661. https://doi.org/10.1016/j.indmarman.2006.04.003

Idris, A. (2008). A profile of innovative women entrepreneurs. International Business Research, 1(2), 3-10. http://dx.doi.org/10.5539/ibr.v1n2p3

Jalbert, S. E. (2000). Women entrepreneurs in the global economy. Report from Centre for International Enterprise, Washington, retrieved from http://www.cipe.org

Jennings, J. E., \& Brush, C. G. (2013). Research on women entrepreneurs: challenges to (and from) the broader entrepreneurship literature?. Academy of Management Annals, 7(1), 663-715. https://doi.org/10.1080/19416520.2013.782190

Kabeer, N. (2005). Gender equality and women's empowerment: A critical analysis of the third millennium $\begin{array}{llllll}\text { development goal } 1 . \quad \text { Gender \& } & \text { Development, } & 13(1), & \text { 13-24. }\end{array}$ https://doi.org/10.1080/13552070512331332273

Kabeer, N. (2016). Gender equality, economic growth, and women's agency: the "Endless Variety" and "Monotonous Similarity" of patriarchal constraints. Feminist Economics, 22(1), 295-321. https://doi.org/10.1080/13545701.2015.1090009

Kaufmann, L., \& Schneider, Y. (2004). Intangibles: a synthesis of current research. Journal of Intellectual Capital. 5(3), 366-388. DOI: https://doi.org/10.1108/14691930410550354

Kepler, E., \& Shane, S. (2007). Are male and female entrepreneurs really that different? Small Business Research Summary. Archive of US Small Business Administration, 309.

Khalique, M., Bontis, N., Shaari, J. A. \& Isa, A. H. (2015). Intellectual capital in small and medium enterprises in Pakistan. Journal of Intellectual Capital, 16(1), 224-238. https://doi.org/10.1108/JC-01-2014-0014

Khalique, M., Shaari, J. A. \& Isa, A. H. (2011). Intellectual capital and its major components. International Journal of Current Research, 3(6), 343-347.

Krueger, N. F., Reilly, M. D., \& Carsrud, A. L. (2000). Competing models of entrepreneurial intentions. Journal of Business Venturing, 15(5), 411-432. https://doi.org/10.1016/S0883-9026(98)00033-0

Langowitz, N., \& Minniti, M. (2007). The entrepreneurial propensity of women. Entrepreneurship: Theory and Practice, 31(3), 341-364. https://doi.org/10.1111/j.1540-6520.2007.00177.x

Lerner, M., Brush, C., \& Hisrich, R. (1997). Israeli women entrepreneurs: an examination of factors affecting $\begin{array}{lllll}\text { performance. Journal of Business } & \text { Venturing, } & 12(4), & 315-339 .\end{array}$ https://doi.org/10.1016/S0883-9026(96)00061-4

Lewis, J., \& Giullari, S. (2005). The adult worker model family, gender equality and care: the search for new policy principles and the possibilities and problems of a capabilities approach. Economy and Society, 34(1), 76-104. https://doi.org/10.1080/0308514042000329342

Lim, S., \& Envick, B. R. (2013). Gender and entrepreneurial orientation: a multi-country study. International Entrepreneurship and Management Journal, 9(3), 465-482. https://doi.org/10.1007/s11365-011-0183-2

Link, A. N., \& Ruhm, C. J. (2011). Public knowledge, private knowledge: the intellectual capital of entrepreneurs. Small Business Economics, 36(1), 1-14. https://doi.org/10.1007/s11187-009-9179-5

Low, M. B., \& MacMillan, I. C. (1988). Entrepreneurship: past research and future challenges. Journal of Management, 14(2), 139-162. https://doi.org/10.1177/014920638801400202

Lumpkin, G. T., \& Dess, G. G. (1996). Clarifying the entrepreneurial orientation construct and linking it to

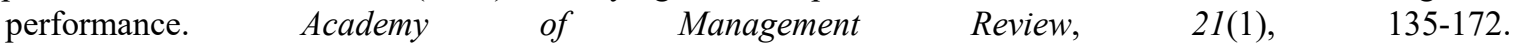
https://doi.org/10.5465/AMR.1996.9602161568

Lumpkin, G. T., \& Dess, G. G. (2001). Linking two dimensions of entrepreneurial orientation to firm performance: The moderating role of environment and industry life cycle. Journal of Business Venturing, 16(5), 429-451. https://doi.org/10.1016/S0883-9026(00)00048-3

Lumpkin, G. T., Cogliser, C. C., \& Schneider, D. R. (2009). Understanding and measuring autonomy: An 
entrepreneurial orientation perspective. Entrepreneurship: Theory and Practice, 33(1), 47-69. https://doi.org/10.1111/j.1540-6520.2008.00280.x

Lyon, D. W., Lumpkin, G. T., \& Dess, G. G. (2000). Enhancing entrepreneurial orientation research: Operationalizing and measuring a key strategic decision making process. Journal of Management, 26(5), 1055-1085. https://doi.org/10.1177/014920630002600503

Matricano, D. (2016). The impact of intellectual capital on start-up expectations. Journal of Intellectual Capital, 17(4), 654-674. https://doi.org/10.1108/JIC-04-2016-0040

Matricano, D. (2017). The influence of sustainable entrepreneurship culture on start-up expectations: A comparative analysis. Rivista di Studi sulla Sostenibilità, 1, 71-89. https://doi.org/10.3280/RISS2017-001006

McClelland, E., Swail, J., Bell, J., \& Ibbotson P. (2005). Following the pathway of female entrepreneurs: a six-country investigation. International Journal of Entrepreneurial Behavior and Research, 11(2), 84-107. https://doi.org/10.1108/13552550510590527

Miller, D. (1983). The correlates of entrepreneurship in three types of firms. Management Science, 29(7), 770-791. https://doi.org/10.1287/mnsc.29.7.770

Minniti, M, Bygrave, W, \& Autio, E. (2006). Global Entrepreneurship Monitor: Executive Report 2005. London, UK: London Business School.

Minniti, M. (2010). Female entrepreneurship and economic activity. European Journal of Development Research, 22(3), 294-312. https://doi.org/10.1057/ejdr.2010.18

Minniti, M., \& Nardone, C. (2007). Being in someone else's shoes: gender and nascent entrepreneurs. Small Business Economics, 28(2), 223-239. https://doi.org/10.1007/s11187-006-9017-y

Mintzberg, H. (1973). The Nature of Managerial Work. Harper and Row, New York.

Montequín, V. R., Fernández, F. O., Cabal. V. A. \& Gutierrez, N. R. (2006). An integrated framework for intellectual capital measurement and knowledge management implementation in small and medium-sized enterprises. Journal of Information Science, 32(6), 525-538. https://doi.org/10.1177/0165551506067127

Musteen, M., \& Ahsan, M. (2013). Beyond cost: the role of intellectual capital in off-shoring and innovation in young firms. Entrepreneurship: Theory and Practice, 37(2), 421-434. https://doi.org/10.1111/j.1540-6520.2011.00477.x

Narayanasamy, K., Rasiah, D., Jacobs, C. J. (2011). An empirical study of factors influencing gender differences in entrepreneurship. International Research \& Economic Research Journal, 10(10), 17-29.

Nelson, G. (1989). Factors of friendship: relevance of significant others to female business owners. Entrepreneurship: Theory and Practice, 13(4), 7-18. https://doi.org/10.1177/104225878901300403

Peña, I. (2002). Intellectual capital and business start up success. Journal of Intellectual Capital, 3(2), 180-198. https://doi.org/10.1108/14691930210424761

Petty, R., \& Guthrie, J. (2000). Intellectual capital literature review: measurement, reporting and management. Journal of Intellectual Capital, 1(2), 155-176. https://doi.org/10.1108/14691930010348731

Plummer, L. A., Haynie, J. M. \& Godesiabois, J. (2007). An essay on the origins of entrepreneurial opportunity. Small Business Economics, 28(4), 363-379. https://doi.org/10.1007/s11187-006-9036-8

Powell, G. N., \& Mainiero, L. A. (1992). Cross-currents in the river of time: conceptualizing the complexities of women's careers. Journal of Management, 18(2), 215-237. https://doi.org/10.1177/014920639201800202

Reynolds, P. D., Bygrave, W. D., Autio, E., Cox, L. W., \& Hay, M. (2002). Global Entrepreneurship Monitor: Executive Report 2002. London, UK: Babson College, London Business School and Kauffman Foundation.

Reynolds, P. D., Camp, S. M., Bygrave, W. D., Autio, E., \& Hay, M. (2001). Global Entrepreneurship Monitor: Executive Report. London, UK: Babson College, London Business School and Kauffman Foundation.

Roos, G., Brainbridge, A., \& Jacobsen, K. (2001). Intellectual capital as a strategic tool. Strategy \& Leadership, 29(4), 21-26. https://doi.org/10.1108/10878570110400116

Roos, J., Roos, G. Dragonetti, N., \& Edvinsson, L. (1997). Intellectual Capital: Navigating in the New Business Landscape. London, UK: Macmillan Business.

Sanchez, P., Chamichade, C., \& Olea, M. (2000). Management of intangibles: the role of strategy, industry 
structure and entrepreneur. Journal of Intellectual Capital, 1(4), 188-209.

Sarasvathy, S. D., Dew, N., Velamuri, S. R., \& Venkataraman, S. (2005). Three views of entrepreneurial opportunity. In Z. J. Acs \& D. B. Audretsch (Eds.), Handbook Of Entrepreneurship Research: An Interdisciplinary Survey And Introduction, New York, NY: Springer.

Sarri, K., \& Trihopoulou, A. (2005). Female entrepreneurs' personal characteristics and motivation: A review of the Greek situation. Women in Management Review, 20(1), 24-36. https://doi.org/10.1108/09649420510579559

Scott, C. E. (1986). Why more women are becoming entrepreneurs?. Journal of Small Business Management, 24, $37-44$.

Shane, S. (2003). A General Theory of Entrepreneurship. The Individual-Opportunity Nexus, Cheltenham, UK: Edward Elgar Publishing.

Shane, S., \& Venkataraman, S. (2000). The promise of entrepreneurship as a field of research. Academy of Management Review, 25(1), 217-226. https://doi.org/10.5465/AMR.2000.2791611

Smith, P., Smits, S. J., \& Hoy, F. (1992). Female business owners in industries traditionally dominated by males. Sex Roles, 26(11), 485-496. https://doi.org/10.1007/BF00289870

Sorrentino, M. (2012). Entrepreneurial issues in competitive strategy research. In G. B. Dagnino (Ed.), Handbook of Research on Competitive Strategy, Cheltenham (UK): Edwar Elgar Publishing.

Sternberg, R., Brixy, U., \& Schlapfner, J. F. (2006). Global Entrepreneurship Monitor: Country Report Germany 2005. Hannover: Institute of Economic and Cultural Geography, Leibnitz University of Hannover.

Stewart, T. A. (1997). Intellectual Capital: The New Wealth of Organizations. London, UK: Doubleday Currency.

Stoner, C. R., Hartman, R. I., \& Arora, R. (1990). Work-home role conflict in female owners of small business: an exploratory study. Journal of Small Business Management, 28(1), 30-38.

Sullivan, P. H. (1999). Profiting from intellectual capital. Journal of Knowledge Management, 3(2), 132-142. DOI: https://doi.org/10.1108/13673279910275585

Sveiby, K. E. (1997). The New Organizational Wealth: Managing and Measuring Knowledge Based Assets. San Francisco, CA: Berrett Koehler.

Thornton, P. H., \& Flynn, K. H. (2003). Entrepreneurship, networks, and geographies. In Z. J. Acs, \& D. B. Audretsch (Eds.), Handbook of Entrepreneurship Research: An Interdisciplinary Survey and Introduction, Sprinter, New York.

Unioncamere - the Italian Association of the Chambers of Commerce, Ministry of Economic Development, Presidency of the Council of Ministers - Department for Equal Opportunities (2016). Impresa in Genere. $3^{\circ}$ Rapporto nazionale sull'imprenditoria femminile. Report retrieved from http://www.imprenditoriafemminile.camcom.it

Venkataraman, S. (1997). The distinctive domain of entrepreneurship research: an editor's perspective. In J. Katz $\&$ R. Brockhouse (Eds.), Advances In Entrepreneurship, Firm Emergence, And Growth, vol. III, Greenwich, CT: JAI Press.

Verheul, I., Uhlaner, L., \& Thurik, R. (2005). Business accomplishment, gender and entrepreneurial self-image. Journal of Business Venturing, 20(4), 483-518. https://doi.org/10.1016/j.jbusvent.2004.03.002

Wales, W. J. (2016). Entrepreneurial orientation: A review and synthesis of promising research directions. International Small Business Journal, 34(1), 3-15. https://doi.org/10.1177/0266242615613840

Wales, W. J., Gupta, V. K., \& Mousa, F. T. (2013). Empirical research on entrepreneurial orientation: An assessment and suggestions for future research. International Small Business Journal, 31(4), 357-383. https://doi.org/10.1177/0266242611418261

Whetten, D. A. (2009). An examination of the interface between context and theory applied to the study of Chinese organizations. Management and Organization Review, 5(1), 29-55. https://doi.org/10.1111/j.1740-8784.2008.00132.x

White, K. M., Smith, J. R., Terry, D. J., Greenslade, J. H., \& McKimmie, B. M. (2009). Social influence in the theory of planned behaviour: The role of descriptive, injunctive, and in -group norms. British Journal of Social Psychology, 48(1), 135-158. https://doi.org/10.1348/014466608X295207 
Wu, W., Chang, M. \& Chen, C. (2008). Promoting innovation through the accumulation of intellectual capital, social capital and entrepreneurial orientation. R\&D Management, 38(3), 265-277. https://doi.org/10.1111/1467-9914.00120-i1

Zanni, L. (1995). Imprenditorialità e Territorio. Cedam, Padova.

Zhang, Z., Zyphur, M. J., Narayanan, J., Arvey, R. D., Chaturvedi, S., Avolio, B. J., Lichtenstein, P. \& Larsson G. (2009). The genetic basis of entrepreneurship: Effects of gender and personality. Organizational Behavior and Human Decision Processes, 110(2), 93-107. https://doi.org/10.1016/j.obhdp.2009.07.002

\section{Copyrights}

Copyright for this article is retained by the author(s), with first publication rights granted to the journal.

This is an open-access article distributed under the terms and conditions of the Creative Commons Attribution license (http://creativecommons.org/licenses/by/4.0/). 